竹腰千絵著

\title{
『チュートリアルの伝播と変容 イギリスからオーストラリアの大学へ』
}

\section{青木麻衣子 \\ (北海道大学)}

本書は、オックスフォード・ケンブリ ッジ両大学で発生した「チュートリアル (tutorial)」と呼ばれる教授形態が、イギ リス国内の他大学およびオーストラリア の大学にどのように伝わり、かつどのよ うな変容を遂げたのかを、両国の高等教 育史をもとに紐解き、「チュートリア ル」とは何かを明らかにしたものである。 本書は、筆者が2016年 3 月に京都大学大 学院教育学研究科に提出した博士学位論 文を基盤とするが、そもそもの研究のき つかけは、筆者が学部在学中に留学した オックスフォード大学で受けたチュート リアルでの衝撃にあったという。いわゆ る受験戦争を経験した世代であればその 背景は共有できるだろうが、筆者にとっ てはこのチュートリアルこそ、主体的に 学ぶことの意義を改めて考えると同時に、 そのおもしろさにも初めて直面した経験 だったに違いない。

本書は、序章と終章を含む全 6 章で構 成される。各章の概要を、以下に紹介す る。序章では、本研究の目的と先行研究 がまとめられている。本研究が対象とす るのはチュートリアルであるが、教授形 態の変更は、当然、教育内容や試験制度、 対象とする学生数や財政状況など大学を 取り巻く様々な時代の変化に影響を受け る。そのため、本書でも、イギリスおよ びオーストラリアの高等教育史ならびに
各大学の大学史が主な先行研究に揭げら れ、これまでのチュートリアルの扱いや その内容・意義についての指摘がまとめ られている。

第 1 章「高等教育におけるチュートリ アル」では、イギリスの大学におけるチ ユートリアルがいつどこで発生し、特に その原型を築いたとされるオックスブリ ッジのチュートリアルの変遷が整理され ている。チュートリアルとはそもそも、 毎週同じチューターにより (1) 1 4人の 学生に対して行われる学生主体 (studentcentred）の教授形態を指す。(2)課題とし てエッセイが課されることが多く、それ をもとにディスカッションを行うのが一 般的な形式とされている。筆者の分析に よれば、これらに加え、(3)ソクラテス的 要素が含まれていること、(4)学問的指導 と道徳的指導が兼ね備えられていること の四点をその特徴とする。パリ大学の力 レッジ (コレージュ) で大学での授業を 補うものとして行われていた復習や討論 の指導は、オックスフォード大学におい て、カレッジのフェローがチューターと して学生の学問的・道徳的指導を行う伝 統へと発展していった。当初はキリスト 教の教義をテキスト通りに学ばせるため の少人数教育が行われていたが、優等学 位試験の導入により、従来の教授形態で は対応ができなくなり、大学外で一対一 
で個人指導を行うプライベート・チュー ターが登場した。そして、それがその後 大学内に取り入れられ今日のチュートリ アルの原型となった。知識の伝達を重視 する指導は、疑問を投げかけて探求する かたちへと変更された。また、試験への 対応から一度学問的なものに偏った指導 のあり方も、道徳的指導を併せもつもの へと変わっていった。

続く第2章「イギリス高等教育におけ るチュートリアルの伝搬と変容」では、 オックスブリッジで形成されたチュート リアルの原型が、19世紀以降、どのよ うに国内他大学に伝わっていったのかを、 ロンドン大学・市民大学への伝播、新大 学への伝播とに分けて提示されている。 チュートリアルそのものは、ロンドン大 学でも市民大学でも、教授形態の見直し やカリキュラムの再編の必要性から取り 入れられたものの、講義中心の授業形態 や実学重視の志向、財政上の理由から、 学生からの要望はあったにもかかわらず、 これらの大学で中心的な教授形態になる ことはなかった。一方、1960～70年代に、 大学進学者数の増加や科学技術の発展へ の対応のため設立された新大学では、政 府の奨励もあり、当初からチュートリア ルが主要な教授形態として導入された。 しかし新大学では、チューターの機能を 分化させるなどして、道徳的指導という 側面が重視された。

第 3 章・第 4 章は、オーストラリアへ と場を移し、それぞれ「イギリスからオ ーストラリアへのチュートリアルの伝搬 と変容」現代のオーストラリアにおける チュートリアル」がまとめられている。
第3章では、オーストラリアで最も歴史 のあるシドニー大学とメルボルン大学を 取り上げ、それぞれの大学の設立の背景 と特徵を整理し、イギリスの大学モデル の伝搬・影響を考察するとともに、チュ ートリアルがそれぞれの大学でどのよう に受け継がれたのかを提示している。ま た、メルボルン大学歴史学科で導入され たチュートリアルが、1960年代以降の 高等教育改革により誕生した大学の教授 形態にどのような影響を与えたのかを、 学生の学習環境をめぐる調査報告書など をもとに示している。戦後の学生増加と 多様化に対応するため、オーストラリア では、チュートリアルをはじめとする少 人数教育を求める声が多く聞かれたが、 財政難などの理由から、各大学ともにそ れになかなか十分には対応できない状況 にあった。そのため、続く第4章では、 現代のオーストラリアの高等教育がその ような課題をどのように乗り越えようと しているのか、チュートリアルはそれに ぞのように貢献しているのかを、一般的 な取り組みとともに、ウェブ等を活用し た新たな形態でのチュートリアルの活用 とともに示している。

最後に終章では、これまでの議論を振 り返るとともに、チュートリアルをチュ ートリアル足らしめる要素について、第 1 章で示した諸点に照らし、整理・確認 している。オックスブリッジで行われて いる伝統的なチュートリアルとオースト ラリアのそれとを比較したとき、明確な ちがいがうかがえるのは、一度に対象と する学生数と目的である。すなわち、オ ックスブリッジでは通常、チュートリア 
ルは、1〜4名を対象にエッセイの指導 として行われるのに対し、オーストラリ アでは、12～20名に対し、講義の理解 の確認や深化を目的に行われている。し かしながら、筆者は、オーストラリアの チュートリアルこそオックスブリッジの チュートリアルの要素を最もよく汲んだ ものであると指摘する。それは、人数や 目的にかかわらず、チュートリアルを教 育活動の中心に位置付け、教授形態の一 つとして価值を見出しているからである。 少人数指導が前提だと考えられてきたチ ュートリアルだが、ウェブ等でそれを代 替する環境があれば、効果的な教育効果 が得られるのではないかとまとめている。 本書における以上のような筆者の指摘 は、この本のテーマが、イギリスおよび オーストラリアの高等教育におけるチュ ートリアルという特定の教授法に焦点を 当てたものであっても、教育段階問わず 主体的な学びの必要性が主張され、かつ 批判的思考力やコミュニケーション力な ぞの汎用的スキルの育成が求められる現 代において意義をもつものである。特に 大学においては、近年、大学院生の教育 経験や指導力の向上を主たる目的にティ ーチング・フェローの導入が進められる など、本書の内容や指摘がそれらの取り 組みの参考になる点も多いだろう。

一方、本書における筆者の整理には、 いくつか疑問をもつた点もある。そもそ も、それぞれの大学の成り立ちや役割が 異なるなかで、各大学における「チュー トルアル」を一様に比較することは可能 なのか。筆者も指摘しているように、才 ーストラリアの大学は当初から大衆に開
かれたものであり、シドニー大学、メル ボルン大学の学生数は、現在でも、オッ クスブリッジの2倍もしくはそれ以上で ある。また、近年では、留学生数の急増 により、学生の多様化への対応も迫られ ている。すなわち、学生の学びの質を効 率的・効果的に維持する上で、「チュー トリアル」に代表される少人数指導が必 要とされたと考えられる。そのため、同 じ「チュートリアル」という名を冠して おり、講義を補完するものとの位置づけ を共有しているとはいえ、両者は、筆者 も整理しているように、チュートリアル を構成する四つの観点ではその内容に相 違が見られるのである。特に、両者の目 指す方向には、大きなちがいがあると考 えられる。しかし、だからこそ、オース トラリアの大学ではなぜ「チュートリア ル」ということばを使い続けるのか、そ の意味を問う必要があるのではないか。 また、本書では、イギリスからオースト ラリアへの伝播を取り上げているが、な ぜカナダやアメリカではなくオーストラ リアなのか。オーストラリアと、例えば カナダやアメリカとの比較を試みること により、筆者の問題関心であるチュート リアルをチュートリアル足らしめる要素 も、より鮮明に浮かび上がるのではない かと考えた。(A5判、187頁、2800円十税、 東信堂、2017 年) 